\title{
Triploid striped catfish Pangasianodon hypophthalmus: growth performance and gonadal development
}

\section{Triploid patin siam Pangasianodon hypophthalmus: pertumbuhan dan perkembangan gonad}

\author{
Yusran Ibrahim ${ }^{1}$, Dinar Tri Soelistyowati ${ }^{2 *}$, Odang Carman ${ }^{2}$ \\ 'Program Studi Akuakultur, Fakultas Perikanan dan Ilmu Kelautan, Universitas Teuku Umar \\ Kampus Universitas Teuku Umar, Alue Peunyareng, Meulaboh, Aceh Barat 23617 \\ ${ }^{2}$ Departemen Budidaya Perairan, Fakultas Perikanan dan Ilmu Kelautan, Institut Pertanian Bogor \\ Kampus IPB Dramaga Bogor, Jawa Barat 16680 \\ *E-mail: sdinarts@yahoo.com
}

\begin{abstract}
This study was aimed to evaluate the growth performance and gonadal development of diploid and triploid striped catfish Pangasianodon hypophthalmus. Triploids were produced through a heat shock method at $42{ }^{\circ} \mathrm{C}$ for two min, at two min after fertilization. Before treatment performed, group of triploid and diploid were separated through nucleolus counting confirmed cromoseme counting. Five individual of each group at the age of nine months were tagged and reared for two months. Parameter of growth performance, feed conversion ratio, and survival rate were analysed using independent-samples t-test at confidence interval 95\%, while gonadosomatic index (GSI) and gonad histology were analysed descriptively. No significant differences were observed between diploid and triploid fish in terms of growth performance, feed conversion ratio, and survival rate $(\mathrm{P}>0.05)$ during the two months rearing period, while GSI was higher in diploid $(\mathrm{P}<0.05)$ compared to triploid females. Histological observations of triploid female gonads showed early development stage, indicating sterility through symptoms such as oocytes degradation and abnormal development. Meanwhile, male gonad developed faster compared to female as spermatids were found in several lobules. As conclusion, diploid and triploid striped catfish $P$. hypophthalmus growth performance did not differ up to the age of 11 months, although some sterility symptoms were observed in both male and female.
\end{abstract}

Keywords: diploid, triploid, growth, gonad, Pangasianodon hypophthalmus

\begin{abstract}
ABSTRAK
Penelitian ini bertujuan untuk mengevaluasi performa pertumbuhan dan perkembangan gonad ikan patin siam Pangasianodon hypophthalmus diploid dan triploid. Triploid diproduksi dengan kejut suhu panas pada suhu $42{ }^{\circ} \mathrm{C}$ selama dua menit, pada dua menit setelah fertilisasi. Sebelum pengujian, kelompok diploid dan triploid dipisahkan dengan menganalisis jumlah nukleolus yang dikonfirmasi dengan penghitungan jumlah kromosom. Masing-masing lima ekor ikan diploid dan triploid pada umur sembilan bulan ditandai dan dipelihara selama dua bulan. Parameter pertumbuhan, rasio konversi pakan, dan kelangsungan hidup dianalisis menggunakan independent-samples t-test pada selang kepercayaan 95\% sedangkan gonadosomatik indeks (GSI) dan histologi gonad dianalisis secara deskriptif. Pertumbuhan, rasio konversi pakan, dan kelangsungan hidup antara diploid dan triploid selama dua bulan pemeliharaan tidak menunjukkan perbedaan yang nyata $(\mathrm{P}>0,05)$. Nilai GSI diploid lebih tinggi $(\mathrm{P}<0,05)$ dibandingkan triploid, baik pada jantan maupun betina. Hasil histologi menunjukkan bahwa gonad ikan patin betina masih pada tahap perkembangan awal. Namun, indikasi steril terlihat dengan adanya degradasi oosit dan perkembangannya yang terganggu. Gonad jantan berkembang lebih cepat dibandingkan betina, dengan ditemukannya spermatid pada beberapa lobule. Gonad jantan triploid menunjukkan adanya gejala sterilitas tetapi tidak permanen, sebagian masih mampu berkembang hingga fase spermatid, namun jumlahnya lebih sedikit dibandingkan diploid. Berdasarkan penelitian, disimpulkan bahwa pertumbuhan antara ikan patin siam diploid dan triploid hingga umur 11 bulan tidak menunjukkan perbedaan, akan tetapi gejala sterilitas ditemukan baik pada jantan maupun betina triploid.
\end{abstract}

Kata kunci: diploid, triploid, pertumbuhan, gonad, Pangasianodon hypophthalmus 


\section{INTRODUCTION}

Striped catfish Pangasianodon hypophthalmus, which is a high economic value commodity, has been widely produced in Indonesia for many years. According to Ministry of Marine Affairs and Fisheries Republic of Indonesia (2016), its price ranges between Rp20,000 and Rp27,000 per $\mathrm{kg}$ for consumption size. The striped catfish fillet industry continues to grow as the demand increases on both local and international markets. However, in the last few years, striped catfish production has been marked by some efficiency problems such as high operational costs, which do not balance with the price on the market. Indeed, the mentioned inefficiency is mainly due to the slow growth performance of the striped catfish, which adversely affects the filet industry.

Triploidization is defined as part of the chromosome set engineering method, which transform a two set chromosome (diploid) into a three set chromosome (triploid). It produces sterile fish with no gonadal development, resulting in a control of wild population, survival rate, growth performance, and meat production increments (Piferrer et al., 2009). Nowadays, triploid fish are widely farmed in Europe because of their ability to overcome various problems, such as early gonadal maturity, which may lead to pre-matured harvest (before the fish reach the targeted weight) of the fish, and it can also prevent genetic interactions between farmed and wild fish (Fraser et al., 2012).

Theoretically, triploid fish shows a better growth performance compared to the diploid one, especially in adult fish, which use the nutrients for somatic growth rather than gonads maturation (Piferrer et al., 2009; Berrill et al., 2012). However, the mentioned theory was not proven for some species such as Atlantic salmon (Taylor et al., 2014) and Gadus morhua L. (Derayat et al., 2013; Ottera et al., 2016), which showed a lower growth performance of triploid compared to diploid.

Triploid fish can be produced by inhibiting the release of the polar body II during the second stage of meiosis, which occurs, in some species, when the zygote reaches 3-7 min of age (Carman et al., 1991). Triploidization can also be done by physical (heat shock, the shock of cold temperature, pressure) and chemical (using anti cleavage substances such as colchicine, vincristine, and cytochalasin) means (Piferrer et $a l .$, 2009). Thus, this study was aimed to evaluate the growth performance and gonadal development of Siamese diploid and triploid striped catfish up to 11 months of age.

\section{MATERIALS AND METHODS}

\section{Spawning, artificial fertilization, triploid induction}

Three matured Siamese striped catfish females at an average body weight of $2-3 \mathrm{~kg} \mathrm{(2-3} \mathrm{years}$ of age) and two matured male weighing 1.5-2 $\mathrm{kg}(1.5-2$ years of age) were used in the present research. The matured fish (males and females) were brought form the Center for Striped Catfish and Catfish Culture Development (from brood stock collection), Cijengkol, Subang, West Java (BPBIPL). Triploidization induction was performed in September 2015 and spawning was artificially done by inducing the females with HCG hormone (500 IU/kg body weight). After a period of $24 \mathrm{~h}$, the females were induced again with ovaprim (GnRH hormone + anti-dopamine) at a dose of $0.6 \mathrm{~mL} / \mathrm{kg}$ body weight. Meanwhile, males were also induced with ovaprim $(0.3 \mathrm{~mL} /$ $\mathrm{kg}$ body weight) and stripped after $8 \mathrm{~h}$. Eggs were washed with a soil suspension after the fertilization process to avoid adhesion. Triploid induction was carried out on zygotes (at the age of two min after fertilization) through heatshock $\left(42{ }^{\circ} \mathrm{C}\right)$ for two min in a styrofoam box $(40 \times 20 \times 20 \mathrm{~cm})$. Eggs were finally incubated in a hatching jar at $28-29^{\circ} \mathrm{C}$ and hatching occurred 20-22 h after incubation. Fertilization level was determined $6 \mathrm{~h}$ after incubation, while hatching rate was determined $2 \mathrm{~h}$ after the eggs hatched. Triploid induction protocol followed throughout this research was based on a preliminary study, which resulted in producing $70 \%$ triploid fish.

\section{Triploid identification}

Diploid (2n) and triploid (3n) identification was done by calculating the nucleolus (Howell \& Black, 1980), which was confirmed by a chromosome counting process (Kligerman \& Bloom, 1977). Nucleoli preparation was performed on fish measuring 2-3 inches (between 2-3 months), while chromosome preparation to confirm ploidy level was done on two weeks old fish. Ploidy level confirmation was carried out by observing the number of nucleoli and chromosomes on the same fish.

\section{Fish rearing}

Diploid and triploid larvae were reared indoor in fiber tube $(3 \times 1 \times 0.4 \mathrm{~m})$ at the same density (for 
all treatments) for three months. Before rearing the fish, they were screened to separate diploid and triploid fish, then kept separately in floating nets $(1 \times 1 \times 0.8 \mathrm{~m})$ at a density of $30 \mathrm{fish} /$ net (for the first three months), and transferred into bigger floating nets $(2 \times 1 \times 0.8 \mathrm{~m})$ for nine months. Both diploid (2n) and triploid (3n) fish were tagged using a passive integrated transponder (TN Pocket tracker), and kept separately in floating nets $(2.5 \times 2 \times 0.8 \mathrm{~m})$ at a density of five fish/net (for two months) in order to determine growth performance and gonadal development. Fish were fed twice daily, at satiation. Data on growth performance and survival rate were collected weekly, while feed conversion ratio was determined every two months. Gonad observations were carried out on ten-months old fish. Data were analyzed with an independent-samples t-test at a level of confidence of $95 \%$, while data on histology were analyzed descriptively.

\section{RESULTS AND DISCUSSION}

\section{Results}

Triploid induction in striped catfish

Fertilization and hatching rates are presented in Figure 1. There was no significant difference found in fertilization rate of the fish egg. Meanwhile post heat-shock $\left(42{ }^{\circ} \mathrm{C}\right)$ of two min old zygote (for two min) resulted in a hatching rate of $80.24 \pm 4.63 \%$ in the diploid group and $27.10 \pm 3.04 \%$ in the triploid group $(3 n)(P<0.05)$, broadly.

Figure 2 shows chromosomes distribution and variations in total number of nucleoli in diploid and triploid striped catfish. The result of observing ten chromosomes distribution showed that diploid fish had 54 chromosomes $(2 \mathrm{n}=54)$ and triploid 81 chromosomes $(3 n=81)$ with a maximum of two and three nucleoli, respectively, in each cell.

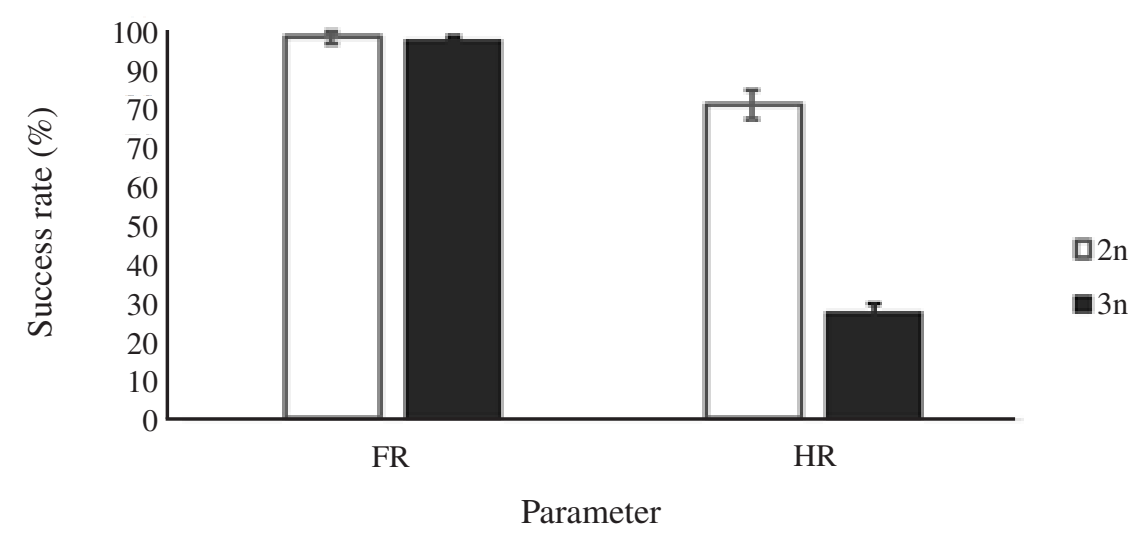

Figure 1. Fertilization rate (FR) and hatching rate (HR) of diploid (2n) and triploid (3n) striped catfish.
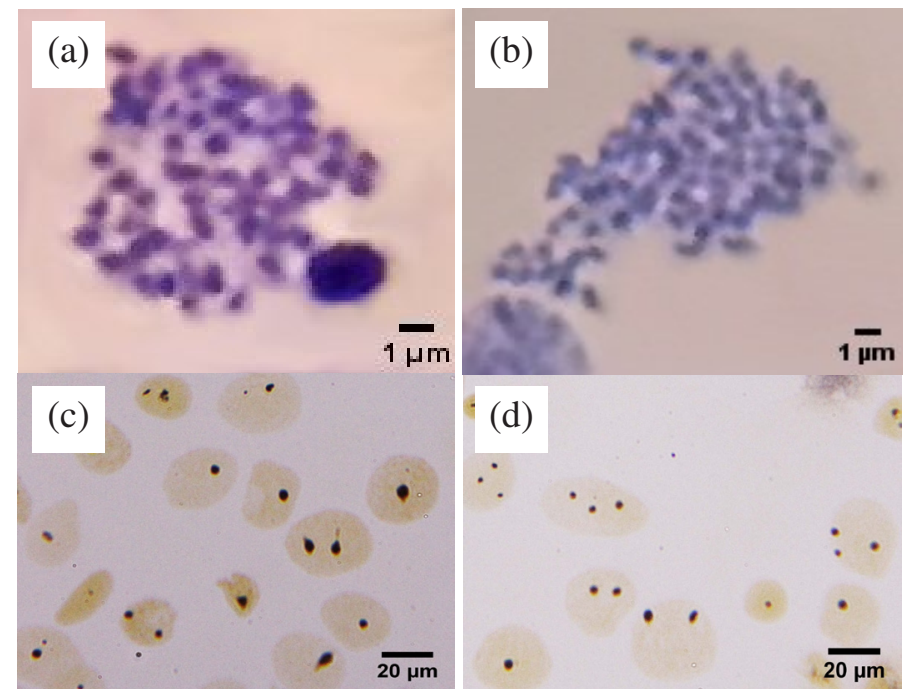

Figure 2. Chromosomes and nucleoli of striped catfish. (a) diploid chromosome, (b) triploid chromosome, (c) diploid cell with a maximum of two nucleoli and (d) triploid cell with a maximum of three nucleoli. 


\section{Growth performance}

Diploid and triploid striped catfish growth Performance are presented in Table 1. A significant difference was observed between diploid and triploid fish in terms of final body weight $(\mathrm{P}>0.05)$, but daily growth rate and feed conversion ratio (during two months) did not differ $(\mathrm{P}>0.05)$.

Gonadosomatic Index (GSI) is presented in Table 2. Gonadosomatic index of both female and male triploid fish was smaller than the diploid one $(\mathrm{P}<0.05)$, indicating disorders in gonadal development.

Macroscopic and microscopic pictures of diploid and triploid striped catfish gonads are presented in Figure 3. Diploid gonad (a1, a2) was observed to be bigger compared to the triploid one (b1, b2). In general, gonadal development is faster in male fish compared to female, since male gonads (a4) reached spermatids phase (SPT), while the female gonads (a3) were still in oocytes pre-vitellogenic phase (OPV). Histology results showed that diploid fish gonads developed normally compared to the triploid, which showed abnormalities. Oocytes degradation (DO) was observed in female gonads (b3), and only a small proportion of oocytes reached the pre-vitellogenic (OPV) phase. An empty space was noticed in triploid male gonads (b4) and only a few of the gonad reach the spermatids (SPT) phase.

\section{Discussion}

Egg or larvae survival as well as the success rate of triploidization greatly depend on the temperature applied during the shock protocol (Maxim, 2008). In addition, egg quality also plays an important part in the triploidization success. The eggs used in the present study were relatively uniform with an average fertilization rate of $98 \%$, but the hatching rate of triploid eggs (group) was lower $(27 \%)$ compared to that of the diploid eggs $(80 \%)$. Similar results were reported in other fish species, such as goldfish and red tilapia, which resulted in 13\% and 36-69\% hatching rates, respectively, post temperature shock (42 ${ }^{\circ} \mathrm{C}$ ) for two min (Carman et al., 1991; Pradeep et al., 2012). The low hatching rate observed in the triploid is a consequence of the heat shock, which disturbed the embryogenesis process. Haffray et al. (2007) stated that triploid induction in rainbow trout through heat shock engendered a low hatching rate, which, however, did not affect the survival rate of the larvae.

Heat shock treatment can generate damages to the microtubule that forms the spindle during meiosis, which in turn, causes harm to the depolymerization process of the tubulin polymers (in the microtubules), which are essential for the spindle formation (Piferrer et al., 2009). In addition, heat shock could also lead to unhatched eggs and when performed at $42{ }^{\circ} \mathrm{C}$ for two min on

Table 1. Growth performance of 9-11 months old diploid and triploid striped catfish

\begin{tabular}{lccc}
\hline \multicolumn{1}{c}{ Parameter } & Age (month) & 2n & $3 \mathrm{n}$ \\
\hline IBW $(\mathrm{g})$ & 9 & $350 \pm 63.6 \mathrm{a}$ & $390 \pm 58.0 \mathrm{a}$ \\
FBW (g) & 11 & $435 \pm 55.0 \mathrm{a}$ & $463 \pm 66.1 \mathrm{a}$ \\
DGR (\%/day) & $9-11$ & $0.34 \pm 0.10 \mathrm{a}$ & $0.39 \pm 0.16 \mathrm{a}$ \\
SR (\%) & $9-11$ & $100 \pm 0.0 \mathrm{a}$ & $100 \pm 0.0 \mathrm{a}$ \\
FCR & $9-11$ & $2.32 \pm 1.16 \mathrm{a}$ & $2,25 \pm 0.76 \mathrm{a}$ \\
\hline
\end{tabular}

Different superscript letter on the lines indicate no significant differences between treatments $(\mathrm{P}>0,05)$. Note: $\mathrm{IBW}=$ initial body weight, $\mathrm{FBW}=$ final body weight, $\mathrm{DGR}=$ daily growth rate, $\mathrm{SR}=$ survival rate, $\mathrm{FCR}=\mathrm{feed}$ conversion ratio, $2 \mathrm{n}=$ diploid and $3 \mathrm{n}=$ triploid.

Tabel 2. Gonadosomatic index (GSI) of diploid and triploid striped catfish

\begin{tabular}{lccc} 
& Sex & Age (month) & \multicolumn{2}{c}{ GSI (\%/body weight) } \\
& & $2 \mathrm{n}$ & $3 \mathrm{n}$ \\
\hline Male & 10 & $1.54 \pm 0.88 \mathrm{~b}$ & $0.11 \pm 0.02 \mathrm{a}$ \\
Female & 10 & $0.25 \pm 0.08 \mathrm{~b}$ & $0.03 \pm 0.00 \mathrm{a}$ \\
\hline
\end{tabular}

Different superscript letter on the lines indicate significant differences between treatments $(\mathrm{P}<0.05)$. Note: GSI= gonadosomatic index, $2 n=$ diploid and $3 n=$ triploid. 


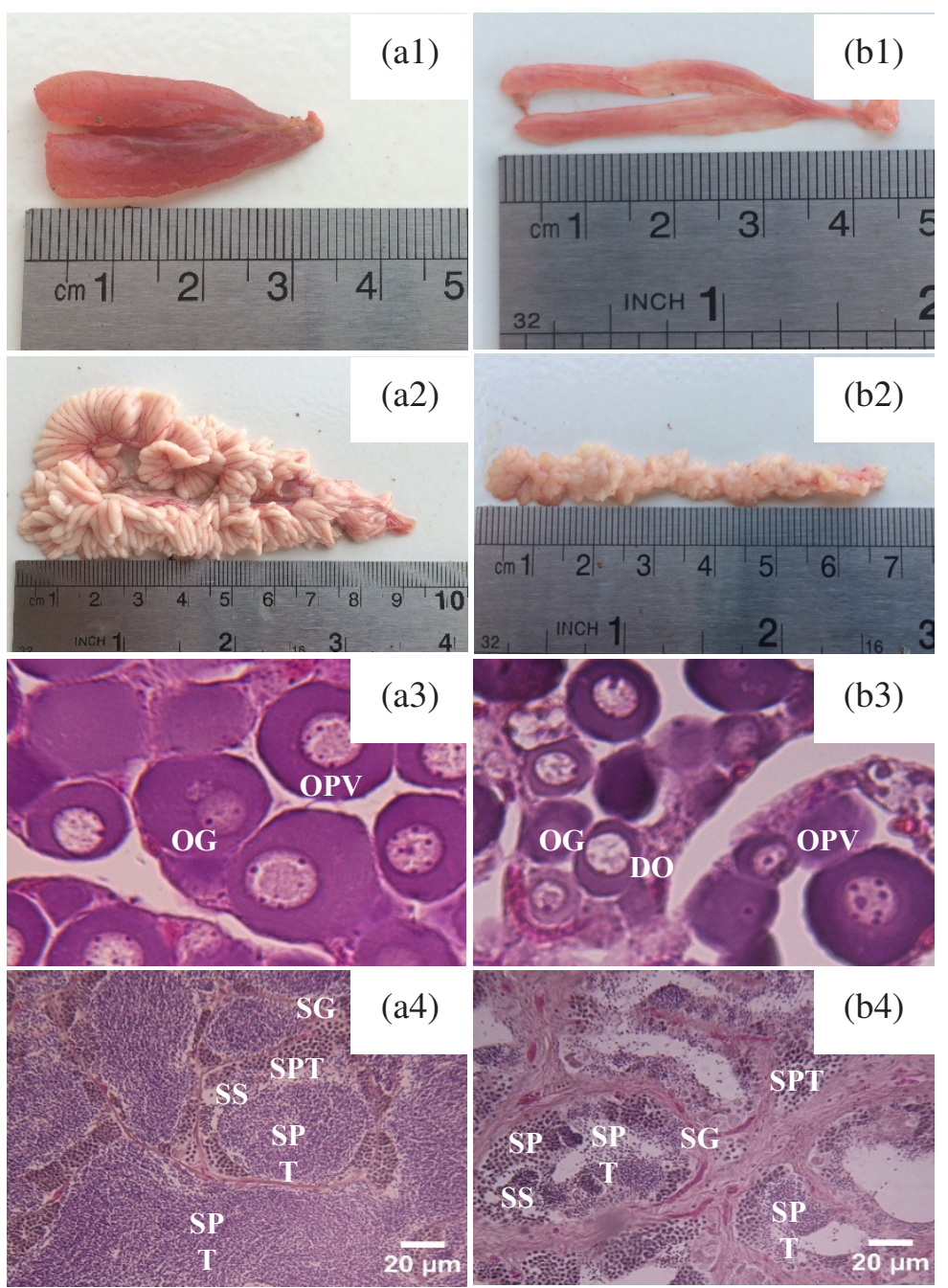

Figure 3. Macroscopic pictures of diploid female (a1), triploid female (b1), diploid male (a2) and triploid male (b2), Gonad histology of diploid female (a3), triploid female (b3), diploid male (a4) and triploid male (b4), Oocytes degradation (DO), oogonia (OG), pre-vitellogenic oocyte (PVO), spermatogonia (SG), primary spermatocytes (PS), secondary spermatocytes (SS), spermatids (SPT).

zygote (at the age of two min after fertilization), it produced $70 \%$ triploid, which was the best result observed in the preliminary study. The use of the heat shock treatment, its duration, the age of the zygote and a proper handling are the key factors to generate high hatching rate and success rate in triploid.

Different fish species would have different chromosome number, which was confirmed in the current research by determining the number of chromosomes in both diploid $(2 n=54)$ and triploid $(3 n=81)$ striped catfish. In addition to the chromosome number determination, the ploidy status was also established by calculating the number of nucleoli. The results indicated that both diploid and triploid fish have a maximum of two and three nucleoli per cell, respectively, and the diploid is dominated by a single nucleoli cell, whereas the triploid by a double nucleoli cell.
All the tested fish were reared in similar conditions with the same feeding regime. Results of the present study showed that triploidization has no effects on some parameters i.e. feed conversion ratio, survival rate, and daily growth rate of striped catfish aged $9-11$ months $(\mathrm{P}>0.05)$. Diploid $(435 \pm 55.0 \mathrm{~g})$ and triploid $(463 \pm 66.1$ g) striped catfish, reared in floating net, did not engender any significant difference in terms of final body weight $(\mathrm{P}>0.05)$. Improvements in triploid fish growth performance depends not only on the fish species but also on the gonadal development activities. In some fish species, the effects of the triploidization on the growth performance could be only seen once the gonad starts developing until its final maturation or in matured fish. Similar trends were reported in Dicentrarchus labrax (Felip et al., 2009) and tiger shrimp (Pongtippatee et al., 2012). 
GSI level was lower in triploid fish compared to diploid, indicating that the gonadal development was disturbed (sterile). In theory, triploid fish, which is sterile (or no gonadal development), is expected to grow better than diploid fish, due to the use of gonadal development energy for somatic growth. However, the histology test results showed that striped catfish gonad did not enter yet its final development phase within the 11 months period of experiment, indicating the need for further observation. In addition, Gonad histology demonstrated a fast gonadal development in male fish compared to female, and diploid male gonads reached the phase of spermatid, while only a few triploid male gonads reached the same phase, on average.

In addition, triploid male gonad is believed to have the ability of producing sperm (but in a small quantity), indicating that the sterilization was not permanent. Spermatogenesis in triploid fish showed a double spermatogonia during the process towards the spermatid phase, which was found to be infertile and became an aneuploid sperm candidate that last until the embryo or larva phase only (Peruzzi et al., 2009; Feindel et al., 2010). The difference between diploid and triploid was already noticeable through oocytes degradation leading to sterility. Gametogenesis disorders causing sterility in triploid fish has been reported repeatedly in fish such as tench (Flajshans et al., 2010), carp (Yu et al., 2011), and Gadus morhua (Feindel et al., 2011).

\section{CONCLUSION}

Growth performance of diploid and triploid Pangasianodon hypophthalmus did not differ up to the age of 11 months. Testes and ovaries of the triploid catfish showed abnormality symptoms, which did not cause permanent sterility.

\section{ACKNOWLEDGEMENTS}

The authors would like to thank to the Indonesian Educational Fund Management Institution (LPDP) and the Center for Striped Catfish and Catfish Culture Development (BPBIPL), Cijengkol, Subang, West Java for the financial support as well as the facilities support.

\section{REFERENCES}

Berrill IK, MacIntyre CM, Noble C, Kankainen M, Turnbull JF. 2012. Bio-economic costs and benefits of using triploid rainbow trout in aquaculture: Reduced mortality. Aquaculture Economics and Management 16: 365-383.

Carman O, Oshiro T, Takashima F. 1991. Estimation of effective condition for induction of triploidy in goldfish Carassius auratus Linnaeus. Journal of the Tokyo University of Fisheries 78: 127-135.

Derayat A, Magnusson A, Steinarsson A, Bjornsson B. 2013. Growth and gonadal development in diploid and triploid Atlantic cod Gadus morhua L. Fish Physiology and Biochemistry 39: 1195-1203.

Feindel NJ, Benfey TJ, Trippel EA. 2010. Competitive spawning success and fertility of triploid male Atlantic cod Gadus morhua. Aquaculture Environment Interactions 1: 4755.

Feindel NJ, Benfey TJ, Trippel EA. 2011. Gonadal development of triploid Atlantic Cod Gadus morhua. Journal of Fish Biology 78 : 1900-1912.

Felip A, Carrillo M, Zanuy S. 2009. Older triploid fish retain impaired reproductive endocrinology in the European sea bass Dicentrarchus labrax. Journal of Fish Biology 75: 2657-2669.

Flajshans M, Gela D, Kocour M, Buchtova H, Rodina M, Psenicka M, Kaspar V, Piackova V, Sudova E, Linhart O. 2010. A review on the potential of triploid tench for aquaculture. Reviews in Fish Biology and Fisheries 20: 317-329.

Fraser TWK, Fjelldal PR, Hansen T, Mayer I. 2012. Welfare considerations of triploid fish. Reviews in Fisheries Science 20: 192-211.

Haffray P, Aubin J, Houis V, Labbe L, Jalabert B. 2007. Comparison of pressure or thermal treatments on triploid yields and malformations up to swim up stage in rainbow trout Oncorhynchus mykiss. Aquaculture 272: 62-65.

Howell WM, Black DA. 1980. Controlled silver staining of nucleolus organizer regions with protective colloidal developer: a 1-step methods. Experientia 36: 1014-1015.

Kligerman AD, Bloom SE. 1977. Rapid chromosome preparations from solid tissues of fishes. Journal of the Fisheries Research Board of Canada 34: 266-269.

Maxim V. 2008. The physiology of triploid fish: current knowledge and comparisons with diploid fish. Fish and Fisheries 9: 67-78.

Ministry of Marine Affairs and Fisheries 
Republic of Indonesia. 2016. Warta perikanan Indonesia: Info harga ikan rata-rata di tingkat eceran http://www.wpi.kkp.go.id/info_harga_ ikan. Diakses pada 07 September 2016.

Ottera H, Thorsen A, Karlsen O, Fjelldal PG, Morton HC, Taranger GL. 2016. Performance of triploid Atlantic cod Gadus morhua L. in commercial aquaculture. Aquaculture 464: 699-709.

Peruzzi S, Rudolfsen RG, Primicerio M, Frantzen, Kauri'c G. 2009. Milt characteristics of diploid and triploid Atlantic cod Gadus morhua L. Aquaculture Research 40: 1160-1169.

Piferrer F, Beaumont A, Falguière JC, Flajšhans M, Haffray P, Colombo L. 2009. Polyploid fish and shellfish: production, biology and applications to aquaculture for performance improvement and genetic containment. Aquaculture 293: 125-156.

Pongtippatee P, Laburee K, Thaweethamsewee $\mathrm{P}$, Hiranphan R, Asuvapongpatana
S, Weerachatyanukul, Srisawat T, Withyachumnarnkul B. 2012. Triploid Penaeus monodon: sex ratio and growth rate. Aquaculture 356-357: 7-13.

PradeepPJ,SrijayaTC,BahuleyanA, Renjithkumar CR, Jose D, Papini A, Chatterji AK. 2012. Triploidy induction by heat-shock treatment in red tilapia. Caryologia: International Journal of Cytology, Cytosystematics and Cytogenetics 65: 152-156.

Taylor JF, Bozzolla P, Frenzl B, Matthew C, Hunter D, Migaud H. 2014. Triploid Atlantic salmon growth is negatively affected by communal ploidy rearing during seawater grow-out in tanks. Aquaculture 432: 163-174.

Yu F, Xiao J, Liang XY, Liu SJ, Zhou GJ, Luo KK, Liu Y, Hu W, Wang YP, Zhu ZY. 2011. Rapid growth and sterility of growth hormone gene transgenic triploid carp. Animal Reproductive Biology 56: 1679-1684. 